\title{
HOMOFOBIA, SUBSTANTIVO INEXISTENTE: UMA POLÍTICA QUEER PARA A HOMOSSEXUALIDADE
}

\section{HOMOPHOBIA, A NONEXISTENT NOUN: A POLICY FOR QUEER HOMOSEXUALITY}

\author{
Guilherme Copati* \\ Adelaine LaGuardia**
}

Resumo: A discussão em torno da homossexualidade e da homofobia, esta última tomada como mecanismo de poder exercido pelo viés do discurso, permite relativizar os limites discursivos da heterossexualidade compulsória e apresentar a proposta de uma política queer para a homossexualidade. A leitura de um artigo de opinião veiculado por Veja propõe uma possibilidade de intervenção militante crítica ao homossexual, pautada em formas subversivas de ativismo e na construção de coalizões abertas para a ação política.

Palavras-chave: Homofobia. Homossexualidade.Teoria queer.

\begin{abstract}
The discussion of homosexuality and homophobia, the latter understood as a set of regulatory discourses, reveals the discursive limits of compulsory heterosexuality and proposes a queer politics of homosexuality. The analysis of an article published by Veja aims at presenting possibilities for a critical militant intervention on the part of homosexuals, based upon subversive forms of activism and the construction of open coalitions aimed at political action.
\end{abstract}

Keywords: Homophobia. Homosexuality. Queer theory.

\footnotetext{
"Mestre em Letras - Teoria Literária e Crítica da Cultura - UFSJ. Bolsista do Programa de Incentivo à Pós-Graduação - PIPG/UFSJ. Docente no Instituto Federal de Educação, Ciência e Tecnologia, Campus Barbacena. e-mail: jbcopati@ yahoo.com.br

"Doutora em Letras pela Universidade Federal de Minas Gerais. Professora Associada da Universidade Federal de São João del-Rei, atuando na graduação em Letras e no mestrado em Letras - Teoria Literária e Crítica da Cultura. e-mail: adelaine@ufsj.edu.br.
} 
O QUE SE ENTENDE POR HOMOFOBIA

Sob uma perspectiva discursiva, pode-se argumentar que a homofobia é uma forma de imposição de poder e de controle sobre os corpos, o que se dá por meio da construção de discursos identificatórios e normalizadores que, segundo Michel Foucault (2007), constroem um saber sobre a sexualidade. Para Foucault, o poder se instaura como estrutura rizomada suportada em múltiplos discursos, sendo estes reafirmados à medida que os saberes sobre a sexualidade são reproduzidos, perspectiva que se abre para o estudo das identidades de gênero, em especial pelas leituras queer que Eve Kosofsky Sedgwick (1990) e Judith Butler (1990) entabulam partindo da noção de poder como ordem discursiva, presente no pensamento de Foucault. Entretanto, o debate em torno do gênero como uma construção do poder que visa a normatizar os indivíduos e forçá-los à assunção da heterossexualidade tem sido questionado por discursos políticos radicais, os quais situam a heterossexualidade tanto como expressão sexual natural e alijada da construção performativa do gênero, quanto como origem perene de discursos homofóbicos.

Ao contrário, tais discursos estão imbricados na rede de construções performativas que tecem a relação dos indivíduos com suas identidades de gênero e que, em função de um efeito de naturalidade criado a partir da repetição e da imitação da heterossexualidade, os posiciona em espaços diferentes de subjetivação ou abjeção em função do grau de propriedade com que performatizam a heterossexualidade. Por isso, a homofobia pode ser mais bem compreendida como uma ação de poder que subjuga todas as identidades de gênero, desde aquelas que atendem às injunções heteronormativas até as que as contestam. Isso ocorre na medida em que a homofobia emerge da construção de alteridades centradas no binário hétero/ homo e, ao posicioná-las em patamares valorativos diferenciados em função da maior ou menor adesão aos pressupostos heteronormativos, confere maior ou menor agência aos indivíduo sem atenção a sua identidade de gênero, sem, contudo, engendrar um espaço de exterioridade teoricamente originária de discursos homofóbicos.

O agenciamento do homossexual no espaço público está condicionado à revelação de sua homossexualidade, o que, para Sedgwick, seria um indicativo de homofobia, em especial porque "sair do armário" implica a perturbação da identidade erótica daquele que assiste à revelação, já que supõe incoerências na heterossexualidade compulsória sobre a qual a heteronormatividade social é construída. "Sair do armário" pode se configurar, ainda, como uma assunção tácita da condição de homossexual. Ao perturbar as certezas e os valores culturalmente instituídos como norma, a revelação de que se é homossexual - ou o mero indício de que possa sê-lo - é recebida com violência, na tentativa de que seja refreada, para que, assim, a ordem cultural que institui a heterossexualidade como padrão de comportamento sexual e afetivo possa ser reproduzida.

A homofobia é, para Sedgwick, uma força histórica e, sobretudo, uma condição sine qua non de estruturação da cultura, compreendendo-se cultura no sentido das condições de inteligibilidade do humano, alicerçadas sobre a heterossexualidade e a 
reprodução sexual da espécie. Nesse sentido, é necessário que a homofobia opere para que a heteronormatividade continue a funcionar como motor do assujeitamento e do condicionamento da conduta sexual dos indivíduos. Assim, ignorar a existência de uma configuração histórico-cultural, que estamos denominando aqui "homofobia", significa minar qualquer chance de agenciamento favorável a mudanças nas estruturas da cultura, e nas normas que a compõem. Como explica Sedgwick, "onde a homofobia ambiente certamente parece ser a própria urdidura do significado nos mais importantes nexos da cultura, a apresentação de qualquer intervenção cuja força não dependa de seu reconhecimento pode parecer uma tarefa impossível, ou impossivelmente isolada". (op. cit., p. 245, tradução nossa)

O que Sedgwick está chamando de uma "homofobia ambiente" diz respeito a normas internalizadas de conduta que, de discretas e imperceptíveis, tornam-se aclimatadas, normalizam-se, não sem a interferência de enormes formas de violência que tentam enquadrar os indivíduos em condutas interessantes ao poder, forçando-os a construir identidades de gênero assimiláveis do ponto de vista de uma "inteligibilidade cultural”. Esse termo é empregado por Butler para indicar os limites das identidades de gênero que são interessantes à manutenção da centralidade conferida à heterossexualidade, e que serão construídas nos indivíduos por meio da assunção de características pertinentes ao espólio heteronormativo, bem como da repressão de traços que se distanciam dele. Por conseguinte, Butler argumenta que as identidades de gênero são construídas como performatividade, fundadas sobre atos discursivos reiterados que constroem uma relação entre corpo, sexualidade, desejo e prática sexual,e cujos limites instituem como condutas aceitáveis apenas aquelas que se submetem aos interesses da heteronormatividade.

Richard Miskolci (2012) apresenta a homofobia como uma forma de "terrorismo cultural", que evoca o medo da violência e a ameaça de retaliações como meio de normalização das condutas e de imposição da heterossexualidade. Partindo desses pressupostos, pode-se pensar a homofobia como um construto complexo que, se aparentemente age de forma a cercear o espaço de atuação pública para gays e lésbicas, acaba por, discursivamente, forçá-los a adequarem-se a uma identidade de gênero heterossexual, inteligível, assimilável - "normal".

Para Miskolci, a abjeção é um elemento que contribui para compor a força histórica da homofobia, especialmente quando compreendida como uma forma de violência que expulsa para fora do círculo de aceitação aquele indivíduo que não corresponde a identidades esperadas de gênero. Uma das primeiras teóricas da homossexualidade a levantar a problemática da abjeção foi a socióloga Mary McIntosh (1968), ao defender a ideia de que a criação, para o homossexual, de um papel social passível de desprezo e punição serviu à necessidade de manter um ideal de pureza para o restante da sociedade. Miskolci observa, por sua vez, que a abjeção é direcionada não propriamente à orientação sexual, mas a condutas que deslocam modelos de gênero socialmente aceitos. Portanto, gays e lésbicas serão, em tese, menos propensos à ação da abjeção, desde que atendam a expectativas impostas pela heteronormatividade, como a adesão ao modelo de família nuclear e monogâmica. 
Percebe-se que a problemática concepção da homofobia se insere não apenas nas lutas pelos direitos políticos e constitucionais da comunidade LGBT, mas, principalmente, em uma dinâmica mais poderosa, que é a da heteronormatividade e das normas que ela exacerba para melhor exercer o poder e o controle sobre os corpos sexuados. Construídas a partir da imposição da heterossexualidade compulsória e de seus dispositivos de funcionamento, tais normas reproduzem configurações sociais que continuam a supervalorizar a heterossexualidade e deslegitimar formas alternativas de desejo e de família.

A revista Veja do dia 14 de novembro de 2012 veiculou o artigo "Parada gay, cabra e espinafre", de autoria de J. R. Guzzo, a propósito de incoerências envolvendo dados estatísticos quanto à Parada do Orgulho Gay de São Paulo, uma das maiores do mundo. O resultado do artigo foi uma enorme polêmica nas redes sociais, angariando, por um lado, a revolta da comunidade LGBT pelo suposto preconceito expresso nas palavras do autor, e, por outro, o suporte de indivíduos que se reservam o direito de não aceitar a homossexualidade e considerá-la, sobretudo, como uma doença a ser tratada.

Em seu artigo, Guzzo afirma que "não há proveito algum para os homossexuais [...] na facilidade cada vez maior com que se utiliza a palavra 'homofobia'; em vez de significar apenas a raiva maligna diante do homossexualismo, como deveria, passou a designar com frequência tudo o que não agrada a entidades e militantes da causa gay” (op. cit., p.117). Essa noção reducionista de homofobia ignora sentidos mais sutis sobre a ação de práticas discursivas que dão sustentação a valores socioculturais. Ironicamente, ao defender a inexistência da homofobia, de suas causas e seus efeitos sociais, o texto em questão fomenta o próprio exercício da ação homofóbica por meio de um discurso denegatório que se constrói em defesa da heteronormatividade, reproduzindo valores socialmente aceitos e menosprezando a experiência histórica de indivíduos LGBT por meio de uma leitura parcial e incompleta da homossexualidade e de sua inserção no campo da cultura.

$\mathrm{O}$ artigo de Guzzo exemplifica o modo como a heteronormatividade opera em duas frentes complementares: a primeira, reconhecendo-se a si própria como norma inquestionável a ponto de ser naturalizada; e a segunda, excluindo do campo de inteligibilidade cultural a aceitação de formas de desejo e expressões sexuais que desafiam sua autoridade. A leitura que o jornalista propôs é interessante por refletir uma visão de mundo compartilhada por inúmeros brasileiros, e por demonstrar uma reflexão pouco profunda sobre as formas de normatização social que todos, sem exceção, somos violentamente forçados a assumir.

A proposta das seções seguintes deste texto é a de uma leitura do artigo veiculado pela Veja com o objetivo de demonstrar não simplesmente que seu autor promove uma desqualificação da causa gay - o que se fará evidente - mas, sobretudo, de apontar que essa desqualificação é uma dinâmica peculiar à heteronormatividade, operando no interior de configurações de poder específicas que objetivam uma reprodução de normas estáveis e aceitáveis de gênero pela via da heterossexualidade compulsória. O intuito será, ainda, questionar os paradigmas valorizados no texto, para demonstrar, por meio de uma visão queer, que eles são sólidas construções culturais objetivadas em controlar as sexualidades e reforçar valores socialmente institucionalizados e aceitos. 
O QUE SE ENTENDE POR QUEER

Butler afirma que o queer é uma nova política de gênero. Surgindo como um impulso crítico em relação à ordem sexual contemporânea, está associado aos movimentos sociais dos anos 1960, que tinham como proposta crítica a subversão da ordem epistemológica centrada em valores masculinos, heterossexuais, brancos e de classe média, e dominante das relações de saber e poder no Ocidente. Entretanto, se naquele momento a demanda por inclusão e reconhecimento social imperava no seio das discussões em torno do gênero, o queer se volta para um questionamento dos paradigmas normativos das políticas inclusivas, apresentando-se como uma política pós-identitária que subverte o valor atribuído discursivamente à heteronormatividade. Por essa razão, a política queer não é pautada pela inclusão ${ }^{1}$, mas pela valorização das diferenças e pela exposição de demandas feitas a partir de sujeitos no sentido de trazer à tona as normas que os criam. Para melhor atender a esse objetivo crítico, o queer concebe o gênero como uma construção cultural e problematiza as bases mesmas da cultura que constrói os indivíduos por meio de processos violentos de sujeição, a fim de revelar as normas ocultas que regulam essa construção.

Dessa forma, pode-se considerá-lo uma política fundamentada em uma revolução das subalternidades, que propõe

1 Políticas inclusivas podem escamotear uma intolerância fundadora que emerge a cada momento que as certezas e convenções culturais do grupo são abaladas, ao passo que uma política queer da diferença faz perspectivar o próprio caráter aleatório e construído dessas convenções e convida a um olhar desentronizador sobre as normas culturais. uma releitura da cultura por meio de experiências historicamente inviabilizadas para desconstruir quaisquer pressupostos de neutralidade sobre os quais se assentam as certezas culturais. Sob a ótica do gênero, o queer procura superar a visão do sexo como fator biológico, questionando a atribuição de naturalidade conferida à heterossexualidade e questionando seus valores mais essenciais, como o casamento, a família nuclear e a monogamia. Para isso, procura expor a violência homofóbica que faz valer normas socialmente ratificadas de sexualidade.

No Brasil, Guacira Lopes Louro (2008) foi a primeira a acenar para as possibilidades que o queer oferecia para uma intervenção política eficaz no campo da educação, a partir da necessidade de questionar o caráter disciplinador das práticas pedagógicas, bem como de revelar uma visão da escola como mecanismo normalizador de condutas e pórtico de ensino de formas corretas de amar, centradas na experiência heterossexual. A pedagogia queer surge a partir dessa dinâmica, atendendo à necessidade de descentramento e de desafio de normas, que se faz premente quando as diferenças emergem como ponto de análise.

O termo queer, proveniente da língua inglesa, que significa "estranho, esquisito, bizarro", foi, historicamente, associado ao homossexual e à própria homossexualidade como encarnação do abjeto. Entretanto, a problemática queer não é a da homossexualidade em si, mas a da abjeção, uma vez que o homossexual alinhado às normas e demandas sociais centradas na ordem sexual heteronormativa também pode ser apontado como 
reprodutor e mantenedor dessa ordem. Por isso, não se pode confundir o queer com o movimento gay ${ }^{2}$. Assim sendo, a leitura que se segue sobre a homofobia e a homossexualidade tem como objetivo um olhar desconstrutor sobre as imposições sociais exacerbadas na figura do homossexual, a fim de apresentá-lo como uma figura histórica e uma construção discursiva que se modifica de acordo com as mudanças nas configurações de poder. Por outro lado, procura-se observar como o homossexual é sistematicamente pensado em termos de valores conservadores e normalizadores que constituem a ordem social do presente, ordem esta que exige uma reflexão crítica e expositora de seu insidioso funcionamento. Finalizando, faz-se necessário pensar algumas possibilidades para uma política queer para a homossexualidade em relação às atuais demandas do movimento gay, propondo formas críticas de militância para uma postura combativa possivelmente mais eficaz.

O QUE SE ENTENDE POR HOMOSSEXUAL (PARA ALÉM DE UMA ONTOLOGIA DO GÊNERO)

Por que a polêmica em torno do texto de J. R. Guzzo, publicado pela revista Veja? Certamente, porque o texto mobiliza

2 Uma crítica às próprias demandas desse movimento pode revelar uma postura um tanto quanto conservadora nascendo do centro de suas reivindicações, funcionando em prol da reprodução da heteronormatividade, e pode, ainda, deslindar gestos paradoxalmente homofóbicos partindo de homossexuais, direcionados àqueles indivíduos que, embora também questionem identidades heterossexuais de gênero, não cooptam com a tessitura social centrada em ideias heteronormativas. questões fundamentais para as culturas as questões ligadas às identidades de gênero. $O$ estudo do gênero, que se desenvolveu a partir de aprofundamentos nas incursões teóricas das feministas, tem se mostrado um importante campo de compreensão sobre distinções constitutivas radicais em determinadas culturas ocidentais, como a distinção entre natureza e cultura, entre o masculino e o feminino, ou entre o heterossexual e o homossexual.

A primeira pensadora a levantar a ideia da distinção entre sexo e gênero, em oposição ao materialismo então dominante no pensamento feminista, foi Gayle Rubin (1975), ao propor o conceito dos sistemas de sexo/gênero para explicar o modo como identidades de gênero são impostas sobre a matriz biológica e genital preexistente, de forma a constituir homens ou mulheres como sujeitos da cultura. Aliando essa visão a um estudo da antropologia estrutural, Rubin postula que as relações de parentesco contribuem para firmar laços culturais entre indivíduos em função de uma construção homossocial na qual os homens, portadores de uma identidade social, estreitam vínculos familiares uns com os outros ao disporem das mulheres e entregá-las ao casamento ou tomá-las por esposas. Essa seria uma tentativa de explicar a opressão das mulheres para além de sua condição biológica, postura dominante no feminismo radical então em ascensão. O que interessa a uma leitura queer do ensaio de Rubin, contudo, para além de uma primeira visão sobre o caráter construído, portanto não essencial, das identidades de gênero, é notar a desvinculação en tre o sexo morfológico e a identidade de gênero heterossexual 
compulsória, que distingue os sujeitos entre os aceitáveis e os abjetos ${ }^{3}$.

Butler vai além dessa proposta construcionista tanto para radicalizá-la quanto para problematizá-la. Segundo a filósofa norteamericana, assumir uma identidade de gênero diz respeito à própria constituição do indivíduo como tal, como pessoa. Por outro lado, a personalidade veria a si mesma questionada diante da emergência de identidades de gênero que escapassem às imposições regulatórias heteronormativas. Partindo dessa reflexão, o homossexual pode ser pensado como uma dessas categorias de aparente monstruosidade que colocam em cheque os valores mais necessários da sociedade, vinculados à assunção de uma identidade inteligível, que mantenha uma relação de coerência e continuidade entre sexo, gênero, prática sexual e desejo. Logo se vê que a homossexualidade constitui um problema de gênero quando pensada em sua dimensão complexa e não-ontológica, que desafia normas imprescindíveis de identidade, sexualidade e mesmo de pessoalidade, centradas na imposição da heterossexualidade e delimitadoras de uma problemática cultural que envolve a aceitação desses indivíduos no círculo da cultura.

30 estudo de Rubin alia duas perspectivas: a psicanalítica e a antropológica. Ao observar tribos diversas, Rubin nota que, em determinadas tribos, um indivíduo portador da genitália feminina pode ser considerado um homem e vice-versa, adquirindo o direito de desposar outro indivíduo, portador da mesma genitália. Partindo dessa e de outras observações, ela desenvolve o conceito de sistemas de sexo/gênero, uma tentativa incipiente de desvincular a morfologia sexual da identidade de gênero. Contudo, os sistemas de sexo/gênero, de fato, não admitem a possibilidade da homossexualidade, uma vez que, mesmo nas relações entre indivíduos portadores do mesmo sexo morfológico, a dicotomia de gênero hetero-orientada permanece como paradigma identificatório dominante.
Apesar disso, o texto de Guzzo se inicia por uma negação da natureza desse problema de gênero. Nas palavras do colunista,

já deveria ter ficado para trás no Brasil a época em que ser homossexual era um problema. Não é mais o problema que era, com certeza, mas a verdade é que todo o esforço feito há anos para reduzir o homossexualismo a sua verdadeira natureza - uma questão estritamente pessoal - não vem tendo o sucesso esperado. [...] Para a maioria das famílias brasileiras, ter filhos ou filhas gay é um desastre - não do tamanho que já foi, mas um drama do mesmo jeito. (op. cit., p. 116)

Afinal, ser homossexual no Brasil é ou não um problema, um drama e um desastre? $\mathrm{O}$ argumento se mostra contraditório, mas, para além da falácia de negar uma problemática social - que é uma forma sutil de imposição de valores e de manutenção de uma ordem vigente que visa reproduzir estruturas sociais interessantes ao poder a recusa que salta aos olhos é a delimitação da homossexualidade como "questão estritamente pessoal”. A questão da homossexualidade, ou de qualquer outra forma de expressão sexual, envolve tanto a satisfação libidinal quanto a assunção de uma identidade de gênero, processo que se dá no seio da cultura, e que necessariamente envolve um posicionamento do sujeito diante das leis que o constituem e que o interpelam perante os demais. Por isso, toda forma de sexualidade desviante relaciona o indivíduo que desafia as imposições de gênero aos demais, que porventura as 
corroborem, de modo a gerar ações corretivas, proibições ou tentativas forçosas de enquadramento a identidades inteligíveis, o que se dá pela mobilização de mecanismos de poder que vão da injúria à desqualificação das identidades dissidentes. De que outra forma se poderia compreender a ação da homofobia, como mecanismo regulador das identidades de gênero, senão como um processo que extrapola o pessoal para envolver algoz, vítima e testemunha?

O próprio desejo, que é um aspecto central para a compreensão das construções de gênero, conforme nos mostram as considerações de Butler, precisa ser pensado como uma dinâmica que circula entre o físico, o psíquico e o social. O desejo será algo a se experienciar a partir da conivência com, ou discrepância de normas reguladoras dos corpos e das sexualidades. Foucault demonstra que essas regulações acontecem, muitas vezes, por meio da ação das instituições como a medicina, a família, a escola, a ciência, que promovem uma centralidade do desejo e da sexualidade como assuntos a serem geridos por práticas controladoras que operam no nível das relações sociais.

Por outro lado, já que a homossexualidade é, também, um drama familiar, seria impossível delimitá-la como questão estritamente individual. A participação da família nesse processo envolve o drama da revelação que Sedgwick discute em seu trabalho, e que diz respeito à quase obrigação de o homossexual "sair do armário" na esperança de ter legitimada sua existência como sujeito do desejo. A família, segundo esse raciocínio, é uma representação metonímica da sociedade, à qual o homossexual é convidado a prestar contas de seus atos, desejos e relacionamentos, o que constitui a existência de sua sexualidade como assunto antes público do que pessoal.

Em função dessa suposta questão estritamente pessoal, que se revela improcedente, Guzzo argumenta que a antipatia em torno de homossexuais tem sido um efeito da Lei das Consequências Indesejadas, isto é, tem sido um efeito colateral inesperado de toda uma movimentação que procura discutir os preconceitos contra homossexuais, atribuir visibilidade pública e midiática à causa política de sua luta, e acaba gerando uma animosidade maior do que a harmonia idealisticamente proposta. Aqui, ele está se referindo às polêmicas levantadas pelo "kit gay", produzido pelo Ministério da Educação no Brasil para distribuição em escolas, e que teve uma recepção péssima de professores, pais e pedagogos, porque "acabou ficando com toda a cara de ser um incentivo ao homossexualismo [e por] sugerir aos estudantes que a atração afetiva por pessoas do mesmo sexo é a coisa mais natural do mundo" (op. cit., p. 116).

A polêmica envolvendo a recepção do "kit gay" não pode ser maior do que a que envolve as afirmações acima. Afinal, tal afirmação é contrassensual ao ignorar o argumento de que a cultura opera no sentido de forçar os indivíduos a identidades heterossexuais, e jamais à homossexualidade. De qualquer forma, seria possível incentivar alguém a assumir determinada identidade de gênero? Seria a experiência do desejo determinada em termos de uma real escolha, opção, ou em termos de uma imposição, de uma construção complexa cujos alicerces compreendem a estruturação da psique em relação a normas sociais que regulam a produção dos corpos sexuais?

Esses questionamentos permitem supor como certo que a homossexualidade 
não seja a coisa mais natural do mundo assim como a heterossexualidade também não o é. Butler argumenta que o gênero e a sexualidade são construídos de modo performativo, isto é, por meio da reiteração de discursos e atos estilizados, os quais conferem a aparência de uma ontologia essencial às identidades de gênero e criam um efeito de naturalização da heterossexualidade. Por meio desse raciocínio, Butler logra questionar os binarismos que constituem a percepção cultural de que a heterossexualidade é a orientação natural dos indivíduos e a homossexualidade seu derivado imitativo, para mostrar que o sexo, a sexualidade, o gênero, e mesmo os próprios corpos, são produtos da reiteração de discursos escamoteados em práticas reguladoras. Segundo a pensadora, é em consequência da construção do binário masculino/feminino a caracterizar os sexos e conferir-lhes a aparência de naturalidade biológica, que o próprio binarismo dos gêneros e a heterossexualidade compulsória são, também, construídos como naturais.

A heterossexualidade compulsória é, portanto, um dos aspectos que trabalham em função da regulação dos corpos, por meio de medidas coercitivas e técnicas disciplinares que obrigam os indivíduos a "performatizar" a heterossexualidade, mantendo, neles, a aparência de que ela é natural. Por outro lado, a emergência do homossexual catalisa um questionamento dessas práticas reguladoras e do próprio valor da masculinidade heterossexual como forma máxima de expressão do desejo, uma vez que a homossexualidade possibilita a relativização do poder de uma economia sexual falocêntrica centrada na virilidade e na masculinidade, bem como evidencia o ca- ráter não natural dessa e de qualquer outra identidade de gênero.

Por outro lado, o gay power, bandeira do movimento LGBT em favor de uma normalização da homossexualidade, também precisa ser criticamente pensado como uma marca em favor da naturalização da homossexualidade nos termos da pureza e da inteligibilidade cultural, bem como de sua submissão a discursos regulatórios centrados na aceitabilidade de determinadas identidades de gênero. Miskolci destaca que a bandeira do gay pride foi provavelmente levantada por uma classe homossexual branca letrada que buscava uma imagem limpa e aceitável da homossexualidade para além do estigma da abjeção, corporificada em uma demanda de aceitação social e de inclusão do homossexual no círculo das identidades de gênero inteligíveis. Por outro lado, uma perspectiva queer sobre a homossexualidade tem como objetivo não a inclusão, mas a revelação de demandas sociais e poderes disciplinares que conformam os indivíduos à vivência de uma sexualidade aceitável e condicionam a postulação da luta política em termos de políticas de inclusão e diversidade.

Nesse caso, como se poderia compreender a chamada "causa gay" e suas demandas? Para J. R. Guzzo, "o primeiro problema sério quando se fala em 'comunidade gay' é que a 'comunidade gay' não existe - e também não existem, em consequência, o 'movimento gay' e suas 'lideranças'. (op. cit., p. 116). Partindo dessa premissa, é premente interpor a pergunta: existiria, portanto, o próprio gay? E, caso exista, seria possível - e mesmo necessário - delimitá-lo como identidade coerente e unificada, ou caracterizá-lo nos termos da ontologia que essa premissa toma como fundamental? 
A figura do homossexual nem sempre existiu como tal. É certo, porém, que a prática sexual entre indivíduos de mesmo sexo existiu desde sempre, conforme comprovam os relatos de pensadores gregos como Platão (1997). Em O banquete, por exemplo, Platão apresenta, por meio da figura de Aristófanes, a mitologia da homossexualidade como busca pela metade masculina perdida. Mary McIntosh sugere, por sua vez, que, durante a Idade Média, as relações sexuais entre indivíduos de mesmo gênero sobrevinham em práticas isoladas ou reincidentes, passíveis de condenação (em especial religiosa), e que, em determinadas culturas, o engajamento de indivíduos em atividade homossexual em algum momento da vida é aceitável, e mesmo esperado. Por outro lado, a partir do século dezessete, ela identifica o surgimento de uma subcultura homossexual rudimentar, em especial na Inglaterra, associada à afeminação e à prática do travestismo. Entretanto, se na Grécia antiga e durante a Idade Média a relação sexual entre homens caracterizava a construção de uma sociedade homossocial, a homossexualidade como prática que fundamenta uma política identitária só será discutida a partir do século dezenove, com a criação da categoria homossexual pelos discursos médicos da sexologia e da psicanálise (FOUCAULT, op. cit.).

Foucault apresenta o homossexual do século dezenove como uma espécie de indivíduo, fruto de uma especificação das práticas e de uma instalação das perversões. Anteriormente compreendido como um reincidente na prática da sodomia, que era tanto um gesto contra a natureza quanto um gesto contra a lei, o homossexual passa a um indivíduo discursivamente criado como uma personagem, um sujeito com uma história pregressa, portador de uma fisiologia possivelmente misteriosa, para quem nada escapa ao princípio insidioso de sua sexualidade que sempre se trai. Trata-se de uma natureza singular, de uma "androginia interior" ou de um "hermafroditismo da alma" (op. cit., p. 51), ou de uma predominância da tendência à homossexualidade durante toda a vida afetivo-sexual do indivíduo. Os "invertidos", "missexuais" ou "pederastas", como foram denominados pela medicina e psicologia em diferentes momentos daquele século, portavam a confusão das fronteiras entre o masculino e o feminino e tornavam-se espécies a serem patologizadas.

Essa figura do homossexual vai subexistir ao longo dos primeiros anos do século vinte e parece mesmo assombrar a construção simbólica do homem gay na contemporaneidade. McIntosh observa que essa figura traz embutida a noção da homossexualidade como uma condição inerente ao indivíduo, quando, de fato, deveria ser compreendida como um papel social, definindo-se "papel" em termos de expectativas passíveis ou não de serem cumpridas: a expectativa da conduta predominantemente homossexual, a de que ele será afeminado em suas maneiras, a de que qualquer relação que estabeleça com outros homens trará um interesse sexual escondido, e a de que será sexualmente atraído por garotos e homens jovens, e disposto a seduzi-los. A descrição da homossexualidade como papel é interessante, mas exclui por completo a experiência de todos os homossexuais que não sejam homens, o que demonstra uma ainda valorização excessiva das experiências de homens na construção dos sujeitos do discurso, da história, e mesmo da academia. 
Já na segunda metade do século vinte, o homossexual se impõe como um sujeito da militância política pró-gay rights, a qual, como revela Eliane Borges Berutti (1999), foi viabilizada em meados dos anos 1960 pela ação de protestos contra a conformidade social e pela colocação de agendas políticas por diversas minorias, dentre elas gays e lésbicas. A professora atenta para a construção de uma subcultura homossexual marcada pela necessidade contraditória de o gay, a um só tempo, disfarçar sua identidade de gênero e organizar um ativismo político. O surgimento, nesse momento histórico, de bares, clubes ou associações gays já indica uma necessidade de militância que será fortemente combatida pelas instâncias públicas institucionais, como a polícia, o governo e as políticas públicas.

Berutti lembra ainda que no interior do próprio movimento pelos direitos políticos dos homossexuais nos anos 1960, determinadas cisões foram impostas. Homossexuais negros experienciaram a revelação de sua sexualidade de modo mais violento, já que encarnavam o desafio de coadunar as demandas por liberdade de expressão sexual com as lutas civis da comunidade negra, em especial na América do Norte. Por outro lado, se as lésbicas não se identificavam com a agenda do movimento feminista, nem sempre se percebiam em completa conformidade com os interesses do movimento gay. Portanto, é importante delimitar que o homossexual associado ao século dezenove e ao movimento gay dos anos 1960 em diante é, em geral, o branco da classe média letrada, que de alguma forma atende às prerrogativas heteronormativas de controle, inclusão e massificação. Por outro lado, do interior do próprio feminismo e mesmo do movimento gay, surgirão focos alternativos de resistência que propõem uma diversificação da militância homossexual pela proposição de questões específicas de mulheres, negros, militares, transexuais.

Mary del Priore (2011) identifica a existência de uma subcultura homossexual também no Brasil, principalmente em grandes centros urbanos como o Rio de Janeiro e São Paulo, para onde convergiam gays e lésbicas de todo o país atendendo à tentativa de escapar às pressões familiares e à necessidade de busca por trabalho. A partir dos anos 1960, com a revolução sexual e as decorrentes transformações da intimidade, o homossexual passa a ser uma figura visível, uma personagem contemporânea, ao lado do transexual e de outras novas "espécies”, presente, por exemplo, nas pornochanchadas e nas revistas pornográficas. Entretanto, o surto da AIDS e sua construção discursiva como a "peste gay" tornaram mais difícil e chocante a revelação da identidade sexual homossexual, reforçando o caráter abjeto de gays e lésbicas, agora erigidos como a imagem do doente castigado e convertidos em símbolo de promiscuidade e libertinagem.

Já para Butler, a homossexualidade como uma identidade de gênero é passível de uma construção por meio de discursos reiterados, que vão determinar o homossexual como uma identidade desafiadora das normas do gênero. Em detrimento de uma metafísica da substância, que determina que o indivíduo é um determinado gênero ou o possui, Butler postula as identidades de gênero contra uma ontologia essencializante, e a favor de um efeito de práticas discursivas, como já explicado anteriormente. 
Sodomita reincidente ou personagem individual, sujeito da medicina, do ativismo ou da história, papel social ou efeito de práticas discursivas reiteradas, as diferentes interpretações possibilitam observar quão complexa é a figura do homossexual, mas desautorizam a pressuposição de que não exista uma "comunidade gay", ou uma "causa gay" da qual participam os próprios sujeitos homossexuais. Caso realmente não existissem, o colunista não estaria tão empenhado em refutar suas demandas e deslegitimar sua experiência. Por outro lado, sua afirmação de que "a tendência [de homossexuais] a olharem para si mesmos como uma classe à parte, na verdade, vai na direção exatamente contrária à de sua principal aspiração - a de serem cidadãos idênticos aos demais" (op. cit., p. 116) parece compreender erroneamente que a segregação da homossexualidade é um indicativo da não existência de sua figura central, quando, de fato, parece indicar uma ramificação do movimento gay em função de demandas específicas a seus diversos integrantes.

Dentre essas demandas, o direito de homossexuais ao casamento tem sido foco de muito debate na contemporaneidade. Para o colunista da Veja, o casamento é um direito de limites muito claros:

o primeiro deles é que o casamento, por lei, é a união entre um homem e uma mulher; não pode ser outra coisa. Pessoas do mesmo sexo podem viver livremente como casais, pelo tempo e nas condições que quiserem. [...] Mas a sua ligação não é um casamento - não gera filhos, nem uma família, nem laços de parentesco (op. cit., p. 117).
O casamento, o parentesco e o tabu do incesto são o foco de abordagens da antropologia estruturalista, da psicanálise e da teoria queer sobre o gênero. Embora os laços familiares, como Gayle Rubin já discutiu em sua abordagem antropológica do gênero, sejam construções culturais que independem do sexo do indivíduo, fica claro que o trecho destacado acima corrobora a ideia heterossexista de que o casamento é uma instituição específica à heterossexualidade. Porém, a discussão em torno do casamento gay é um fato inegável na contemporaneidade, que precisa ser adequadamente problematizado.

Segundo del Priore, a onda de doenças sexualmente transmissíveis deflagrada pela liberação sexual proporcionou um retorno tradicionalista a valores como casamento e família, o que pode fornecer uma justificativa para a demanda cada vez mais frequente pelo direito à união homoafetiva. Por meio dela, homossexuais engajados em relações estáveis podem assinar um termo de valor legal semelhante ao do contrato de união estável, que garante, por exemplo, benefícios previdenciários a companheiros homossexuais. Entretanto, a união homoafetiva ainda não garante a possibilidade de disposição da herança, já que a legislação brasileira considera apenas a união entre homem e mulher como uma entidade familiar estável. Partindo dessa problemática, Butler (2004) questiona quais são as bases culturais que instituem o casamento e o parentesco como fulcro sobre o qual são sancionados e legitimados os direitos à saúde, herança, recursos previdenciários e outros, para mostrar que a eleição do casamento como ponto de convergência desses direitos todos afeta não apenas à comunidade homossexual, mas a todos aqueles que divergem de rela- 
ções nucleares monogâmicas, como os solteiros, os avessos ao casamento, os viúvos ou divorciados, os não monogâmicos, e outros vários.

Sob o ponto de vista secular, o casamento pode ser compreendido como uma instituição social que tem por finalidade assegurar a parceria legal entre os cônjuges e garantir a disposição de bens com base em direitos constitucionais. Tradicionalmente, contudo, ele tem sido praticado como forma de forçar relações heterossexuais monogâmicas, em consonância com o discurso religioso e com a moral cristã, sendo essa a noção que fica expressa no texto da Veja: a da lei divina que determina o casamento como privilégio natural da heterossexualidade. Portanto, caberia questionar que a iniciativa mais relevante seria a de desvincular o casamento das relações afetivas e sexuais, e mesmo da contiguidade com a formação de uma família. Mesmo entre heterossexuais, essa instituição poderia ser repensada como um caminho de associação entre indivíduos com benefícios legais e financeiros mútuos, independentemente do tipo de relação afetiva que desempenham em relação um ao outro.

Outra questão, ainda mais complexa e de contornos mais renitentes, é a dos próprios termos sobre os quais se organiza o debate sobre o casamento gay. Nesse sentido, o casamento é considerado como uma forma de legitimação, pelo Estado, da sexualidade e do desejo, o que, na opinião de Butler, constitui um extremo conservadorismo acerca dos dispositivos que podem ditar quais sexualidades são inteligíveis. Articulado em torno dos extremos de aceitabilidade e inaceitabilidade da união entre indivíduos do mesmo sexo, o debate sobre o casamento gay acaba por formalizar uma necessidade de regulamentação e reconhecimento público da sexualidade que estende as formas de legitimação para além da relação heterossexual, porém instala parâmetros mais cruéis de distinção entre legítimo e ilegítimo.

A esse respeito, Miskolci afirma que a luta pelos direitos ao casamento de gays e lésbicas, remetente aos anos 1960 e 70 é, de fato, uma luta em favor da abjeção, embora tenha deslocado seus limites, já que objetivava o reconhecimento da ligação afetiva homossexual como normal. Porquanto, a homossexualidade constituiria uma ligação afetiva que, embora ilegítima, seria passível de legitimação, ao passo que quaisquer relações desempenhadas fora da esfera do casamento e de sua forma alternativa de legalidade seriam exacerbadamente tomadas como ilegítimas. Sob essa perspectiva, uma luta contra a abjeção ousaria questionar não o tipo de indivíduos que se alinham em um relacionamento, mas as bases que postulam a própria necessidade do casamento, da monogamia, da família monocelular, e, sobretudo, da heterossexualidade como modelo normativo de prática sexual, bem como do papel que essas construções todas desempenham na manutenção de ideais estáveis de família, nação e cultura.

O dilema que se impõe em função disso é o da necessidade de legitimação em oposição à instância legitimadora. Afinal, como reflete Butler, é necessário e imprescindível à colocação de uma agenda de políticas identitárias que uma busca por legitimação seja estruturada, ao passo que é também preciso que o Estado seja questionado em seu estatuto de instância reguladora, o que poderia levar a uma compreensão dos laços afetivos e sexuais, mais democrática e 
menos circunscrita a práticas reguladoras e a formas institucionalizadas de violência. Por isso, o debate envolvendo o casamento gay pode servir de ponto de partida para uma reflexão verdadeiramente crítica sobre as instâncias normalizadoras que corroboram os poderes do Estado, de forma a apontar alternativas desafiadoras dos próprios regimes existentes, nos quais ocorre toda prática de legitimação.

Ao mencionar as proibições do incesto e a pedofilia, que seriam supostamente inquestionáveis tanto para homo quanto para heterossexuais, Guzzo se vale de uma generalização - "Ninguém, nem os gays, acha que qualquer proibição dessas é um preconceito" (op. cit., p. 118) -, que supõe o próprio incesto como prática impossível, e sua proibição como efeito natural. Contudo, como Butler discute, o fato de a proibição existir não significa que ela funcione, ao contrário, pode ser que ela venha a criar os meios da própria ocorrência do incesto, ou, pode-se acrescentar, da pedofilia. Por outro lado, questionar o tabu do incesto pode parecer algo simples, mas significa, de fato, lidar com mecanismos profundamente enraizados na psique do indivíduo e nas relações sociais. Por isso, o casamento, que é a confluência forçosa de todas essas proibições e tabus que regulam a sexualidade tanto no nível dos atos sexuais quanto no das relações sociais, se questionado em suas bases, poderá abrir espaço para uma recolocação das proibições concernentes à sexualidade. Afinal, se os laços de parentesco decorrentes do casamento são culturalmente instituídos, uma mudança nas configurações dessa instituição relativizaria as noções de família e os próprios limites do incesto, apenas para dar um exemplo.
A questão do parentesco, relacionado à economia da troca de mulheres na construção da base de toda cultura, tem sido questionada à luz de novas políticas relacionadas à gestação e cuidado de crianças, exemplificadas por políticas de adoção, inseminação artificial, manipulação do genoma, modelos não nucleares de família etc. A adoção de crianças por casais homossexuais tem sido incluída de um modo geral no debate sobre os limites da união homoafetiva, ao mesmo tempo em que reações conservadoras insistem no apego ao caráter religioso ou legal das famílias produzidas pela união heterossexual centrada na reprodução. Uma ruptura com esses modelos, e com a própria série de discursos que os institui como modelos, abriria caminho para uma democratização das uniões que não geram famílias hoje tidas como inteligíveis, ao passo que traria possibilidades de intervenção no modo como se compreende a família e os laços de parentesco em tempos contemporâneos marcados pela relativização dessas noções.

Apesar de tamanhas polêmicas terem lugar, para o colunista da Veja os homossexuais já percorreram caminhos importantes em se libertar da selvageria que marcou sua existência durante séculos, sendo que hoje "não precisam mais levar uma vida de terror, escondendo sua identidade para conseguir trabalho, prover o seu sustento e escapar às formas mais brutais de chantagem, discriminação e agressão" (op. cit., p. 118). Uma leitura apenas superficial do trabalho de Sedgwick, aliada a alguns exemplos elencados ao longo deste texto, demonstrarão o contrário. A homossexualidade, apesar dos aparentes avanços nas formas como a sociedade a percebe, ainda se apresenta como um problema de gênero, um problema 
social, um problema pessoal, uma forma de contrariar normas socialmente estabelecidas de sexualidade e uma prática condenável. Apesar das afirmações de Guzzo, a compreensão mínima que se dá ao fenômeno, hoje, não se deve à natural evolução das sociedades, mas antes ao empreendimento crítico de pensadores e cidadãos leigos que ousam questionar o valor de imposições sociais e revelar a violência subjacente a elas.

Perder de vista esse detalhe essencial é iludir-se com o secundário, o que raramente é uma boa ideia.

O QUE SE ENTENDE POR UMA POLÍTICA QUEER PARA A HOMOSSEXUALIDADE

Para postular devidamente uma política queer que reflita sobre a homossexualidade de modo subversivo e desmistificador, é necessário retornar à consideração da homofobia como um mecanismo regulador, um dispositivo de poder que procura conformar indivíduos a identidades preconcebidas de gênero, produzindo a abjeção de toda identidade que ouse questionar as imposições sociais e os limites da inteligibilidade cultural. Um dos modos pelos quais essa medida ganha força, no texto veiculado pela Veja, é a desqualificação histórica da luta de gays e lésbicas por direitos constitucionais, somada à negação da existência de um problema, numa tentativa de escamotear discursos dominadores centrados sobre o falocentrismo e a heterossexualidade compulsória.

Por meio da negação de uma problemática concernente ao papel do homossexual na constituição das bases da cultura, bem como das questões envolvendo a luta política do movimento gay e, finalmente, por meio de uma valorização absurdamente evidente de concepções heteronormativas, o artigo de J. R. Guzzo produz uma abjeção simbólica do homossexual e se revela um instrumento poderoso da homofobia que o autor alega não existir. $\mathrm{O}$ argumento que endossa a inexistência, ou a não necessidade, de um pensamento crítico sobre a homofobia, bem como de uma mudança de posicionamento social diante da homossexualidade, é extremamente bem construído, mas muito do que Guzzo disse aponta para uma reflexão limitada pelos valores da heteronormatividade.

Uma política queer para a homossexualidade deve, porém, centrar-se não sobre a inclusão do homossexual na lei heteronormativa, ou sobre a valorização de uma visão da homossexualidade como sexualidade pura e inteligível, uma vez que tal postura equivaleria a adequar-se a normas e modelos preexistentes e controladores do desejo. A intenção deve ser a de desvelar a existência violenta de normas homofóbicas, demonstrando os modos como a heteronormatividade se beneficia da manutenção de seus valores, mas questionando, também, a possibilidade de que determinadas identidades de gênero pareçam ser mais frequentemente vitimadas pela violência e marcadas pelo estigma da abjeção.

Em decorrência desse objetivo, a requisição primeira seria a de questionar todo um conjunto de práticas que circunscrevem as sexualidades aceitáveis e descartam as demais, para demonstrar sua não naturalidade, e revelar como operam no sentido de reproduzir estruturas culturais já disseminadas e de referendar um conservadorismo discursivo fundamentalmente situado sobre a prerrogativa de naturalidade de determinadas relações sexuais, bem como de determinadas 
identidades de gênero, e das próprias noções de parentesco e família delas provenientes.

Nesse sentido, tal política precisa abandonar a necessidade de delimitação ontológica de categorias de gênero tais como o gay, a lésbica, a travesti, o transexual, e outras tantas. Todos esses serão, teoricamente, "homossexuais", independentemente dos modos específicos como se configuram seus desejos e a vivência de suas afetividades, na medida em que desafiarem o binarismo homem/mulher ou masculino/feminino sobre o qual se constrói o paradigma cultural heteronormativo. Abandonando-se a tentativa de delimitação conceitual das ontologias de gênero, irromperiam os verdadeiros indivíduos e suas lutas políticas se tornariam mais eficazes.

Por isso, o que se compreende por homossexual vai depender de uma configuração conjuntural, ou de uma coalizão de indivíduos organizados em torno de ideais políticos semelhantes. Para ficar em apenas alguns exemplos, homossexuais brancos e negros poderão, em determinados momentos, articular uma militância conjunta particular às demandas específicas de cada grupo, da mesma forma que homens homossexuais e lésbicas terão a oportunidade de propor uma luta coletiva que momentaneamente suplante as imposições culturais exacerbadas que diferenciam os homens das mulheres na cultura ocidental (por exemplo, a imposição da maternidade). Poderão, assim, questionar essas demandas, implodindo diferenças de raça, gênero, classe social, e outras, em função da articulação de uma luta por direitos políticos mais efetiva porque mais conjunta.

A proposta da coalizão, postulada por Donna Haraway (2009), não pode, contudo, permitir uma delimitação prévia de quais serão os indivíduos envolvidos no processo. Estes surgirão no momento mesmo em que se fizer necessária a luta política, e em função de objetivos conjunturais. Trata-se de um modelo que Butler denomina de "coalizão aberta”, em que a preocupação não é delimitar o que se entende por homossexual. Partindo do modelo da coalizão aberta, uma luta que defina com precisão gestos passíveis de acusação de homofobia poderá ser desenvolvida com maior eficácia.

Por outro lado, tal proposta de agenciamento político precisa ter como pauta uma compreensão crítica das demandas que a própria militância possibilita levantar. Aqui, a discussão mais central foi direcionada à união homoafetiva; a esse respeito, é importante mostrar que, não raro, a luta em favor da legalização do casamento entre homossexuais, embora trouxesse como possíveis benefícios a asseguração de direitos constitucionais referentes à disposição sobre a herança, o compartilhamento de direitos previdenciários, a comunhão de bens, dentre outros, pode mobilizar uma valorização paradoxalmente conservadora de pressupostos ligados à necessidade da monogamia e da família nuclear, ao mesmo tempo em que rearticula o debate em torno de paradigmas de legitimação que constituem interesse especial do próprio Estado. A união legal entre indivíduos, em caráter de casamento, deveria ser assegurada independentemente de sua orientação sexual, identidade de gênero, ou da necessidade de nutrirem algum tipo de relação afetivo-sexual um pelo outro, e mesmo de constituírem uma "família" nos termos de uma relação heterossexual reprodutória. De fato, o que precisa ser foco de questionamentos é o próprio significado de termos como 
"casamento" e "família”, e, sobretudo, o processo de reiteração desses significados que os fazem surgir como naturalizados e inquestionáveis no corpo de nossa cultura. Ater-se a noções religiosas, ou a definições legais pré-históricas, significa excluir de vista possibilidades alternativas no interior de um regime de códigos culturais em constante mutação.

Além disso, o próprio binarismo proibição/permissão precisa ser levado em conta como uma força que gera a adesão acrítica de indivíduos e reproduz uma ordem social centrada na abjeção e na desvalorização histórica de determinadas experiências. Assim, um questionamento dessas demandas sociais possibilitaria ao indivíduo operar em um espaço social radicalmente democrático e sexualmente progressista, em que a legitimação de ligações afetivo-sexuais não fosse condicionada a um desejo maior da religião ou do Estado, estruturadores de toda possibilidade de agenciamento e dos termos nos quais se entendem as relações interpessoais.

Por fim, uma política queer para a homossexualidade, centrada na convergência de indivíduos em coalizões abertas, precisa gradualmente abandonar a necessidade confessional de tornar pública a orientação sexual ou identidade de gênero do homossexual. Já se disse que a publicação da homossexualidade é uma dinâmica violenta que exige do indivíduo trazer a público suas questões mais íntimas. Entretanto, o homossexual astucioso (SANTIAGO, 2012) pode subverter a ordem discursiva que 0 obriga a enunciar sua sexualidade em palavras, para propor, em seu lugar, um silêncio pleno de significados que deixaria de explicitar a violência social contra si mesmo para articular uma forma menos agressiva e, certamente, mais eficiente de militância.

\section{REFERÊNCIAS}

BERUTTI, E. B. The Stonewall Legacy. Transit Circle, v. 2, n. 2. Porto Alegre: ABEA, 1999, p. 59-65. BUTLER, J. Gender trouble: Feminism and the subversion of identity. New York: Routledge, 1990.

Routledge, 2004.

DEL PRIORE, M. Histórias íntimas: sexualidade e erotismo na história do Brasil. São Paulo: Editora Planeta do Brasil, 2011.

FOUCAULT, M. História da sexualidade: a vontade de saber. v.1. Rio de Janeiro: Graal, 2007. GUZZO, J. R. Parada gay, cabras e espinafre. Veja, São Paulo, 14 nov. 2012, p. 116-118.

HARAWAY, D. Manifesto ciborgue: ciência, tecnologia e feminismo-socialista no final do século XX. In: HARAWAY, Donna; KUNZRU, Haria; SILVA, Tomaz Tadeu da (Orgs.). Antropologia do Ciborgue: as vertigens do pós-humano. Belo Horizonte: Autêntica, 2000, p. 37-129.

LOURO, G. L. Um corpo estranho. Ensaios sobre sexualidade e teoria queer. Belo Horizonte: Autêntica, 2008.

McINTOSH, M. The homosexual role. Social problems. v. 16, n. 2, Autumn, p. 182-192, 1968. MISKOLCI, R. Teoria queer: um aprendizado pelas diferenças. Belo Horizonte: Autêntica, 2012.

PLATÃO. O banquete: ou do amor. Rio de Janeiro: Bertrand Brasil, 1997.

RUBIN, G. The traffic in women. Notes on a political economy of sex. In: RIVKIN, Julie; RYAN, Michael. Literary theory: an anthology. Malden: Blackwell, 2004, p. 533-559.

SANTIAGO, S. O homossexual astucioso: primeira - e necessariamente apressadas considerações. In: O cosmopolitismo do pobre. Belo Horizonte: Editora UFMG, 2012. 
SEDGWICK, E. K. Epistemology of the closet.

Los Angeles: University of California Press, 1990.
Recebido para publicação em 30 ago. 2013. Aceito para publicação em 10 jan. 2014. 